stars, and has communicated fifteen papers on that subject to the Society. Mr. Hargreaves has rendered important services to astronomy by the design of valuable instrumental accessories. He has devised an electric drive for telescopes which has been very successfully applied to the 28 -inch equatorial at Greenwich. He also constructed a "comparison image micrometer" with which he made double-star observations with an accuracy which compared very favourably with that of observations made with the filar micrometer. In addition, he has produced mirrors and other work of high excellence. His contributions to astronomical observation have been chiefly in the delineation of planetary detail, but he has given much attention to astronomical photography.

\section{Geological Society of London Awards}

THE council of the Geological Society has made the following awards: Wollaston Medal to Prof. Maurice Lugeon, of the University of Lausanne, in recognition of the value of his researches on the mineral structure of the earth, particularly in respect of the geological structure of the Alps and of mountain building ; Murchison Medal to Dr. Henry Howe Bemrose, in recognition of his researches upon the igneous rocks of the Lower Carboniferous of Derbyshire, and also upon the Pleistocene fauna of the same area ; Lyell Medal to Dr. John Pringle for his services to palæontological science, and particularly in recognition of his work in connexion with the Geological Survey and Museum; Wollaston Fund to Dr. Henry Francis Harwood, of the Imperial College of Science and Technology, in recognition of his research work on the chemistry of minerals and rocks ; Murchison Fund to Dr. Frank Coles Phillips, for his contributions to metamorphism and structural petrology; a moiety of the Lyell Fund to Dr. Sydney Ewart Hollingworth, for his work on the Lower Carboniferous rocks, and the structural geology of the Lake District and northern Pennines, and on the Vale of Eden glaciation; another moiety of the Lyell Fund to Dr. Frederick Murray Trotter, for his geological researches, especially on the glacial and post-glacial phenomena of the Eden Valley.

\section{$\varepsilon$ Aurigæ-a Super-giant Star}

UNTI the requisite details are available in the Astrophysical Journal regarding Dr. O. Struve's discovery of the precise nature of the eclipsing binary system of $\varepsilon$ Aurigæ, no useful comments can here be made. It may be inferred, however, from the Press reports that a study by Dr. Struve of the infrared spectrum of the star obtained with sufficiently high dispersion has shown that the chief component of the system is a super-giant star with a radius some 3,000 times that of the sun. The star of largest radius hitherto known is Antares, the radius of which is about 450 times the sun's. $\varepsilon$ Aurigæ, the light variation of which is of Algol type but with an exceptionally long period of $27 \cdot 1$ years, has long been the subject of intensive observation, mainly in Germany, in the United States and in Canada. The spectroscopic history of the star up to 1928 is summarized in "Handbuch der Astrophysik", 6, Pt. 2, 466 (1928). Results obtained at the Yerkes Observatory by Frost, Struve and Elvey at the last light minimum in 1928-29 are given in the publications of that observatory in vol. 7, Pt. 2. During the same epoch, Adams and Sanford were able to distinguish clearly on their high-dispersion spectra taken at Mount Wilson a faint component on the redward side of the enhanced lines and those of hydrogen. They pointed out the necessity of obtaining high-dispersion spectrograms of $\varepsilon$ Aurigæ at other epochs of the period of light variation in order to trace the origin of the faint spectral component.

\section{Recent Advances in Glass Technology}

TWENTY-ONE years ago was a strenuous period for British technologists, and in no field were the problems more urgent than in connexion with the production of glass for laboratory, optical and many other purposes ; thus the necessity of team-work brought the Society of Glass Technology into existence, and its coming-of-age has recently been celebrated. A series of lectures on "Glass in Modern Life", arranged by the Society in this connexion, recalled some of the veritable struggles of the period of the Great War, and the more ordered progress of this 'key industry' under the subsequent measure of protection accorded to it. Prof. W. E. S. Turner mentioned that the value of the production of the chemical and scientific glassware industries has risen from $£ 129,000$ in 1924 to $£ 250,000$ in 1937 , and is doubtless even higher today. Undoubtedly, the activities of the Society have contributed in no small degree to the possibility of this expansion, and the same is true of Prof. Turner himself and the Glass Technology Department at the University of Sheffield. The term 'glass' covers a very wide variety of chemical substances; when we find it being employed in these days (inter alia) for nuts and bolts, woven fabrics (of course for highly specialized purposes), and bricks for building, we may wonder whether the golden age of glass production is only just beginning. The list of lecturers also included Mr. Raymond McGrath and Mr. Bernard P. Dudding, who dealt with the applications of glass in their special fields of architecture and illuminating engineering respectively; and Dr. W. M. Hampton contributed a lecture on new developments in the field of optical glass. Although the production of optical glass may be a very minor activity from the business point of view, the experience gained in efforts to improve it has been invaluable in its. lessons for the larger-scale operations.

\section{Cave Paintings and Military Operations in Spain}

WHILE anxiety was felt generally throughout the world as to the fate which was likely to befall the artistic treasures of Spain until reassurance was given by Sir Frederic Kenyon's visit of inspection to the scene of hostilities, archæologists were no less perturbed at the thought of the damage which might be done to the priceless palæolithic paintings of the caves of northern and eastern Spain, both within the 
zones of operations. In the current number of L'Anthropologie (47, 5-6) a note is published from the Abbé Breuil to M. R. Verneau, in which it is stated that Prof. H. Obermaier has been informed by a journalist that the famous cave of Altamira, in the neighbourhood of Santander, the best known and most important of the caves, had suffered no serious injury, although it had given shelter to some hundreds of refugees and the house of the guide had been occupied by an officer of the Red staff. Alcade del Rio also is informed that the same is true of the other caves with paintings of the Cantabrian Pyrenees. On the other hand, M. Verneau is told that the greater part of the archæological collection formed by Sen. Perez de Barradas and housed in the Municipal Museum of Madrid, had been broken up. News of the fate of the important paintings in the province of Teruel in eastern Spain will be awaited with no little anxiety.

\section{Palestine Archæological Museum}

THE Palestine Archæological Museum in the newly erected buildings at the north-eastern corner of the city of Jerusalem was opened to the public on January 13, the ceremony, which was to have taken place on January 11 in the presence of the High Commissioner, having been cancelled, owing to the murder of Mr. J. L. Starkey on the previous evening, when on his way to Jerusalem in order to be present. The cost of erecting the buildings has been met in part by a gift of two million dollars to the Government of Palestine by the late Mr. John D. Rockefeller. The site of ten acres, of which the buildings occupy one quarter, was provided by the Government. The architect was Mr. Austen St. B. Harrison. The Museum consists of a central rectangular block, flanked on north and south by buildings around open courts. In addition to the exhibition halls, open to the public, which will house the more striking and important exhibits, galleries are provided for the material which will be accessible to students, while in the basements provision has been made for housing archæological material from excavations and other sources, pending its allocation and distribution. Provision is also made for staff accommodation and library, the latter already consisting of ten thousand volumes, and space being reserved for a further thirty thousand. The Museum will cover the pre-, protoand historic periods, including the Roman, Byzantine and Arab antiquities of Palestine down to A.D. 1700. Among the antiquities now on view are the Galilee skull, the first Neanderthal skull to be found in Palestine, the remarkable collection of prehistoric pottery dating from the Stone Age to the close of the Canaanitish period, and the ivories from the palace of Ahab in Samaria, discovered in the excavations of 1933-35, which are among the most striking objects of æsthetic interest as yet found in Palestine.

\section{Further Exploration of Tell Duweir, Palestine}

APPREHENSION has been felt among archæologists lest the further exploration of Tell Duweir, the Biblical Lachish, should have to be abandoned, owing to the murder of Mr. J. L. Starkey, the director of the Marston-Wellcome Archæological Expedition to the Near East, by whom the mound was being excavated. The death of Mr. Starkey is universally regarded as an irreparable loss to Palestinian studies; but the blow would have been even heavier had it not been possible to continue work on this important site, which has already provided so much valuable material bearing on the interpretation of more than one crucial period in the history of the country and its cultural development. This fear has now been allayed by the announcement that the excavation will continue, at any rate for the present. Arrangements have been made by the High Commissioner for it to be carried on under the supervision of $\mathrm{Mr}$. Lankester Harding, who was recently appointed director of antiquities in Transjordania. Mr. Harding was Mr. Starkey's principal assistant in 1932-36. $\mathrm{He}$ is, therefore, not only well acquainted with the character of the site and the lie of its stratification, but also-and this is of no little importance-he is thoroughly familiar with the scheme of operations, which Mr. Starkey had plotted out in relation to the importance of the areas to be excavated, so far as this could be gauged in advance.

\section{Indian Universities and Nationalism}

THE annual Patna convocation lecture was delivered on November 27 by the vice-chancellor of the parent university of Calcutta, Mr. S. P. Mukherjee. The lecturer, although disclaiming for himself the qualifications of a historian, declared that Indian universities should saturate their alumni with the lessons of Indian history and civilization, and took as his principal theme an interpretation of Indian history coloured to stimulate the "ever-increasing vitality of Indian nationalism" with somewhat bitter references to present "bondage" and "a subject race and the power that wants to hold it in its leading strings". It seems regrettable, though not surprising, that the Indian universities should under the new constitution allow themselves to be used for the purposes of political propaganda. Lord Willingdon recently remarked that Indian politicians used to believe we were not sincere in wanting to help them in their advance towards responsible government but that they trust us now. No such change of heart seems to have been experienced by Mr. Mukherjee.

\section{Earthquake Records at De Bilt}

Dr. E. VAN EVERDINGEN's twenty-second report on the work of the seismological station at $\mathrm{De}$ Bilt continues, for the year 1934, the useful lists in its predecessors (K. Nederl. Meteor. Inst., No. 108; 1936). The station lies about five miles north-east of Utrecht and is provided with horizontal and vertical Galitzin seismographs in addition to Wiechert and Bosch seismographs. The report contains the times as recorded at De Bilt of the different phases of 487 earthquakes, and in most cases gives also useful details on the position of the epicentre, as determined by the records at different observatories, the places at which the earthquake was felt and the intensity at them when known. 